\title{
Kampen om sandheden - Klimavidenskab som aktivisme
}

\author{
Cecilie Glerup \\ Ph.d.-studerende, Institut for Organisation, Copenhagen Business School (CBS) \\ Marie Chimwemwe Degnbol \\ Ph.d.-studerende, Institut for Fødevare- og Ressourceøkonomi, Københavns Universitet (KU)
}

Hvad betyder politiske kulturer for brugen af videnskab? Cecilie Glerup og Marie Degnbol undersøger, hvordan en dansk klima-NGO inddrager videnskab i sine forsøg på at skabe hårdtslående kritik på klimaområdet. Ifølge de to forfattere forsøger NGO'en at bekæmpe „falsk konfliktualitet" - at folk er uenige om klimaforandringernes omfang, fordi de ikke kender den sande karakter af katastrofen. NGO'en ser med andre ord enighed og fællesskab som en betingelse for forandring, noget forfatterne mener er levn fra Grundtvig og Højskolebevægelsen.

Trods en formodet øgning af tropiske storme, tørkeområder og hastigt smeltende gletschere kan forbindelserne mellem menneskers praksis, øgede mængder drivhusgasser i atmosfæren og ændringer i vores miljø endnu ikke etableres med det blotte øje eller almindelig snusfornuft. Videnskabelige tolkninger er nødvendige for at fastslå de delikate forbindelser mellem konkrete hændelser og det globale fænomen 'klimaforandringer'. Selve konstruktionen og afgrænsningen af klimaforandringerne som policyområde er medieret af videnskab. Derfor har diverse videnskabelige udsagn en konstituerende rolle i de politiske kampe om, hvorvidt der overhovedet er et problem, og hvordan man i så fald skal forholde sig. Videnskab spiller således en fremtrædende rolle som omdrejningspunktet for de politiske konflikter omkring klimaforandringerne. Det er til stadighed til debat, hvem der sidder inde med den 'sande' fortolkning af klimaets tilstand, fordi løsningsperspektiverne synes at afhænge af denne fortolkning. For aktivister på klimaområdet handler en stor del af den politiske kamp derfor om at (be)vise klimaforandringernes eksistens og forudsige deres multiple konsekvenser for liv og miljø på kloden. Eksempelvis er den globale klimaNGO 350.org baseret på et estimat om, at indholdet af $\mathrm{CO}_{2} \mathrm{i}$ atmosfæren ikke må overstige 350 parts/million, hvis den globale temperaturstigning skal holdes på 2 grader $C^{\circ}$. 350.org's aktivister laver events og demonstrationer over dette tema mange forskellige steder. Fx dannede danske aktivister vha. egne kroppe tallet 350 på Rådhuspladsen i København ifm. COP15 i 2009; et billede der gik verden rundt og var med i CNN News. Klimavidenskab er således et vigtigt middel til at udøve kritik af gældende politik på klimaområdet. Den bruges til at demonstrere, hvordan klimasituationen ' $\mathrm{i}$ virkeligheden' ser ud og anvise alternative løsninger. Hvis man vil forstå, hvordan politisk kritik skabes blandt aktivister på miljøområdet, bliver studiet af videnskabens rolle derfor et kardinalpunkt.

Videnskabens rolle i samfundet - og selve produktionen af videnskab - har længe været tematiseret $\mathrm{i}$ samfundsvidenskaberne. En lang række sociologiske og antropologiske studier, Laboratoriestudierne, har siden 1970'erne udviklet og forfinet forståelsen af relationerne mellem produktionen af viden og det samfund, hvori denne produktion foregår, på basis af en konstruktivistisk forståelse (fx Barnes \& Bloor 1982; Latour 1983; Latour 1987; Traweek 1988; Knorr-Cetina 1999). Derudover har man vist, hvordan viden skabes mange steder af mange forskellige aktører, ikke blot forskere ( $\mathrm{fx}$ Gibbons et.al 1994; Wynne 1996; Barry 2001; Nowotny 2001; Leander, dette nummer), og hvordan viden opstår og cirkuleres i specifikke kulturelle kontekster og dermed altid tæt sammenvævet med konkrete diskurser og forestillinger (fx Latour 1983; Barry 1999; Jasanoff \& Kim 2009 Horst \& Irwin 2010). Feltet 'Public Understanding of Science' har desuden vist, hvordan videnskabelig videns integration i samfundet afhænger af stærke forestillinger om videnskaben som objektiv og værdineutral ( $\mathrm{fx}$ Irwin 1995; Irwin \& Wynne 1996; Miller 2001; Buys et.al. 2014). Med udgangspunkt i disse indsigter begiver denne artikel sig ud i et lokalt studie af sammenhængen mellem videnskabelig viden og politisk aktivisme. Der er allerede studier af, hvordan politiske protester sætter en sag på den videnskabelige dagsorden (Epstein 1995; Hess 2007; Jamison 2001), men den 'omvendte' analyse 
af, hvordan videnskab indgår i opbygningen af politisk kritik, er sjældnere set, og vi er ikke stødt på studier af, hvordan der i en særligt dansk kulturel kontekst trækkes på videnskab i forbindelse med klimaaktivisme. Nærværende artikel bidrager hertil med en analyse af, hvordan en dansk klima-NGO bruger videnskab i sit forsøg på at skabe en kritik, som med dens egne ord skal „stoppe global opvarmning nu" (Klimabevægelsen 2009).

Hovedspørgsmålet for denne artikel er derfor, hvordan videnskab indgår i konstruktionen af kritik af klimapolitik i en dansk kontekst. Spørgsmålet besvares gennem et casestudie af arbejdet i den danske NGO 'Klimabevægelsen' i Danmark's landsudvalg (herefter LU) op til FN's klimatopmøde i København i 2009. Artiklen viser, hvordan LU vha. bestemte videnskabelige referencer ønsker at skabe folkeligt opråb til politikerne om, at vi som samfund bør sætte alle kræfter ind på at stoppe klimaforandringerne. Videnskaben har to funktioner ift. at nå dette mål: Dels skal den anskueliggøre problemets kolossale omfang, dels skal den qua sin status som værdifri og neutral mobilisere befolkningen på tværs af sociale skel og politiske ståsteder. Videnskaben indgår hermed i konstruktionen af en særlig form for kritik, som består i at opløse, hvad vi (med tak til Marx) har valgt at kalde 'falsk konfliktualitet'. Analysen af LU's konstruktion af klimakritik efterfølges af en diskussion, hvor kritikken sættes i en dansk politisk kulturel kontekst, og der åbnes for diskussioner af perspektiverne i en sådan form for kritik.

\section{Klimabevægelsen i Danmarks Landsudvalg}

„... en demokratisk og folkelig bevagelse, som vil stoppe global opvarmning nu" (Klimabevægelsen 2009). Sådan formulerer Klimabevægelsen i Danmark (herefter KiD) sin vision. KiD blev officielt stiftet i marts 2008. Motivationen for at søsætte en ny NGO var blandt andet frustrationen over den manglende mobilisering af borgere, som ikke nødvendigvis føler sig hjemme i de eksisterende miljøorganisationer, men som er bekymrede for klimaforandringerne. Centralt i bevægelsens diskussioner om, hvilken slags NGO de var i færd med at skabe, var derfor ønsket om at gøre op med den tidligere sammenkobling af venstrefløj og miljøaktivisme. Idéen med $\mathrm{KiD}$ var nemlig at skabe en "folkelig bevagelse" (Klimabevægelsen 2009) med plads til forskellige bevæggrunde og former for aktivisme, men samtidig en bevægelse, der via bred mobilisering kunne „presse beslutningstagere“ til en mere ambitiøs klimapolitik (Klimabevægelsen 2009). Hvorvidt bevægelsens 1000 medlemmer faktisk var i stand til dette - eller præcis hvordan det skulle gøres - er en anden sag. Hovedpointen i forhold til denne artikel er, at det var en bevægelse, som troede på, at man via bred, folkelig modstand kan lægge et pres på nationale og internationale politikere, som så vil arbejde for at mindske klimaforandringerne gennem regulering.

$\mathrm{Vi}$ fattede interesse for $\mathrm{KiD}$, fordi det var en ny $\mathrm{NGO}$, som var i færd med at skabe sig en rolle på den klimapolitiske scene, og fordi vi vidste, at man lagde vægt på formidling af videnskabelig viden som en del af det kritiske projekt. Vi zoomede ind på landsudvalget og fulgte dets arbejde i 9 måneder op til COP15, fordi dette var et rigt forum for diskussioner om NGO'ens kritiske rolle. Dette gav os mulighed for at iagttage det konkrete arbejde med at konstruere kritik, som var indlejret i lange diskussioner om bevægelsens mål, strategier og udfordringer. Konstruktionsarbejdet i LU tjener som en paradigmatisk case (Flyvbjerg 1991, 150) for undersøgelsens forskningsspørgsmål. Med en paradigmatisk case betones for det første, at vi forventede, at brug af videnskab i konstruktionen af kritik ville udfolde sig sarligt her. Dette forventede vi, fordi NGO'en var ny og derfor skulle tage stilling til brugen af videnskabelige udmeldinger om klimaforandringerne i forhold til deres politiske projekt. For det andet fordi diskussionerne afspejler elementer fra den særlige danske 'konsensuskultur', som går tilbage til Grundtvig og højskolebevægelsen (Horst \& Irwin 2010). Her går ideer om dialog og fælles forståelse hånd $\mathrm{i}$ hånd med foragt for autoriteter og en tro på lægmands fornuft (Horst 2012), hvilket vi vil uddybe nærmere i diskussionen. Denne politiske kultur er udbredt i tid og rum, og vi argumenterer for, at den også vil performe i andre danske fora, hvor videnskabelig viden indgår i politiske processer. Trods det faktum, at empirien efterhånden er nogle år gammel, argumenterer vi således for, at den er et typisk eksempel på, hvordan videnskab og politik er gensidigt afhængige på kulturelt bestemte måder. Ærindet med studiet af KiD's LU er derfor ikke at dokumentere en bestemt tid og holdning i organisationens historie, og LU betragtes i denne sammenhæng ikke som repræsentant for den samlede organisation - den var i øvrigt meget decentraliseret. Det er et åbent spørgsmål, hvor meget forbindelse der var mellem LU og de lokale dele af organisationen. Med andre ord, det er som eksempel på, hvordan videnskab og politiske kulturer informerer hinanden, at LU op til COP15 er interessant.

I 9 måneder op til COP15 observerede vi det månedlige møde i LU (9 møder). For også at have forståelse for LU's mange referencer til KiDs konkrete aktiviteter observerede vi desuden forskellige andre aktiviteter, hvor flere af medlemmerne deltog: 4 møder om hjemmesidens udformning og planlægningen af deres 1. Maj-aktion. Vi deltog ligeledes i KiD’s demonstration 1. Maj 2009, KiDs landsmøde september 2009 og besøgte KiD's medlemmer under deres arbejde diverse steder under COP15. Vi sluttede feltarbejdet af med et fokusgruppeinterview 
med LU's 6 medlemmer. Da vi har lovet anonymitet til LU og øvrige KiD-medlemmer, og det jf. vores tilgang (som vil blive præsenteret siden) i øvrigt heller ikke er væsentligt, hvem der indtager hvilke positioner, fremgår der ikke navne i de følgende analyser. Det væsentlige er, at medlemmerne ser sig selv som borgere, der vil gøre en indsats og er 'lægmænd' i forhold til de videnskabelige udsagn. Før vi præsenterer den tilgang, hvormed vi har undersøgt brugen af videnskab i LU's arbejde med at konstruere kritik, introduceres i det følgende det konstruktivistiske blik på kritik og videnskab, som danner grundlag denne artikel.

\section{Kritik og videnskab i et konstruktivistisk perspektiv}

I de følgende analyser vil vi undersøge, hvordan videnskab indgår i konstruktionen af en politisk kritik. Hermed aktualiseres relationen mellem 'politik' og 'videnskab'. En gængs forståelse af fænomenerne 'politik' og 'videnskab' er, at de er to vidt forskellige størrelser, hvor 'politik' forstås som et felt gjort af interesser og magt, mens 'videnskab' er et felt baseret på fakta og rationalitet (Latour 2004 \& 2006). Denne forståelse er dog blevet udfordret, bl.a. af feltet 'Science and Technology studies', hvor man empirisk har vist de mange måder, hvorpå politik og videnskab spiller sammen i konkrete kontekster uden stærkt definerede grænser ( $\mathrm{fx}$ Macnagthen et al. 2005; Latour 2006; Jasanoff 2011). For at kunne studere, hvordan videnskab indgår i konstruktionen af kritik, har vi tilsvarende brug for et begrebsapparat, som muliggør en undersøgelse af de empiriske relationer og afgrænsninger imellem dem, snarere end på forhånd at definere dem som væsensforskellige. I denne artikel forstås 'kritik' som en bestemt form for (studerbar) politisk praksis og 'videnskab' som et fænomen, der optræder i vores empiri i egenskab af socialt legitime sandhedsudsigelser (i dette tilfælde om klimaforandringerne), der indgår i konstruktionen af denne praksis. For at studere sammenhængene betragter vi de to størrelser 'symmetrisk' (Barnes \& Bloor 1982), dvs. at vi som udgangspunkt anser både videnskabelige fakta og politiske udsagn som resultater af forhandlinger i det sociale rum, hvorfor man kan studere årsagerne til deres status og indbyrdes sammenhænge ligeligt.

Vores forståelse af 'kritik', og dermed politisk praksis, er inspireret af Andrew Barry's (1999; 2001) forståelse af begrebet som en bestemt form for praksis, hvor aktører med forskellige greb prøver at udsige en alternativ sandhed om samfundets indretning: Fx om det problematiske i en ny motorvejsstrækning for den lokale fauna, hvordan finansmarkederne ødelægger 'almindelige menneskers' økonomi eller konsekvenserne for den danske befolkning, hvis vandstanden stiger. Grebene, hvormed disse sandheder søges etableret, kan være forskellige: De kan fx være retoriske i form af slogans eller apeller til følelser, de kan være materielle i form af blokader af motorveje eller besættelse af kulkraftværker, de kan være videnskabelige i form af visninger af grafer eller referencer til videnskabelige artikler og rapporter. At etablere alternative sandheder kræver som regel flere forskellige ressourcer, men i denne artikel fokuserer vi på, hvordan referencer til klimavidenskab indgår, og hvilken funktion de har i forhold til konstruktionen af KiD's klimakritik. Derfor er kritik en form for praksis, som opstår i konkrete kontekster, hvor forskellige aktører sammen etablerer udsagn om samfundsindretningen eller (andre) måder at løse en given problemstilling på. En forståelse som er i tråd med den meget praksisorienterede forståelse af kritik indenfor Science and Technology Studies ( $\mathrm{fx}$ Marres \& Rogers 2005). Vha. denne optik kan vi således studere LU's arbejde som konstruktionen af en kritisk praksis, som skal etablere sandheder om klimaforandringerne og nødvendigheden af omfattende politisk regulering for at bremse dem.

Ligesom kritik forstår vi også videnskab som en konstrueret størrelse. At etablere et videnskabeligt 'faktum' kræver en række af ressourcer og greb som fx penge, måleudstyr, kendskab til etablerede standarder for videnskabelig praksis, citationer i tidsskrifter etc (Latour \& Woolgar 1979; Latour 1987). I forlængelse heraf skal videnskab heller ikke forstås som et fænomen, der udelukkende skabes i laboratorier for fikst og færdigt at blive leveret til samfundet 'udenfor'. Et laboratorium er ikke adskilt fra resten af samfundet, viden cirkulerer mange andre steder end $i$ traditionelle vidensproducerende institutioner og videnskabelige fakta bliver omdannet afhængig af den historiske, stedlige og sociale kontekst, som de indgår i (Gibbons et al. 1994, 67). Hermed ikke sagt, at der nødvendigvis bevidst manipuleres med fakta i forskellige kontekster, men at et faktum aldrig kan forstås uden for den sociale kontekst, det agerer i. Uden denne ville et faktum slet ikke give mening. I LU indgår videnskab som en komponent $i$ at udøve kritik, og hvordan LU forholder sig til videnskabelige udsagn kan ikke adskilles fra dette formål. Snarere end videnskabens ophav eller sandhedsværdi er vi altså interesserede i relationerne mellem kritik og videnskabens performative effekter (Butler 1997).

\section{LU som et kritiklaboratorium}

Tilgangen til studiet af KiD's landsudvalg er inspireret af de ovennævnte studier af arbejdet med at konstruere fakta (Latour og Woolgar 1979; Latour 1987). Disse studier viste netop, hvor mange forskellige komponenter der skal bringes til at samarbejde for at skabe et faktum: mi- 
kroskop, diskurser om, hvad der er sandt, pengestærke investorer, at mikroberne lod sig se under luppen, de rette temperaturer osv. (Latour 1983). Tilsvarende betragter vi aktiviteterne i LU som eksperimentelt arbejde i et laboratorium: Det afsøges, hvordan videnskabelige rapporter, idéer om retfærdighed, en bred medlemsskare og hjemmesiden kan kombineres for at konstruere bevægelsens kritik (for lignende greb, se Horst 2003; Sevelsted \& Henriksen 2008; Horst 2008b). Man forsøger at konstruere kritik, som testes, afvises eller modereres, før det forlader 'kritiklaboratoriet' og indgår i kampen mod klimaforandringerne. Ligesom Latour studerede 'facts in the making' (Latour 1987), har vi i LU's kritiklaboratorium dermed kunnet studere 'critique in the making'. Denne tilgang giver os blik for at se hvilke komponenter, der foreslås at indgå i kritikken, hvilke kontroverser, der opstår, og hvordan de forsøges løst ved at forbinde eller afkoble komponenter i bestræbelserne på at skabe KiD's kritiske rolle i klimadebatten.

'Laboratorieudstyret', hvormed forskellige komponenter blandes og testes, udgøres af LU-medlemmernes fælles og divergerende idéer om, hvad der skal til for at skabe „en bred, folkelig bevagelse ..." - herunder forventninger til de potentielle medlemmer, forestillinger om valid klimavidenskab, ambitiøs kritik mv. Det interessante er at følge, hvordan konstruktionen af KiD's kritik via diskussioner testes i spændingsfeltet mellem de holdninger, forståelser og forventninger, der er repræsenteret i kritiklaboratoriet. Således kan vi studere, hvordan videnskab om klimaforandringerne inddrages i kritikkonstruktionen. Vi kan fx se hvilke idéer om forholdet mellem politik og videnskab, der er på spil, og hvordan og hvorfor bestemte videnskabelige udsagn om klimaforandringerne udvælges. Og vi kan se, hvordan videnskab om klimaforandringerne forbindes med andre komponenter som $\mathrm{fx}_{\mathrm{x}}$ bestemte idéer om oplysning og dialog, i forventning om at disse forbindelser vil kunne skabe en 'alternativ sandhed' (Barry 1999) om klimaforandringerne.

Under konstruktionsarbejdet i kritiklaboratoriet skete der fortfarende kategoriseringer af videnskab og politik som en del af arbejdet med at konstruere KiD's kritik. Thomas Gieryns begreb om 'boundary work' (herefter 'grænsearbejde') (Gieryn 1983, Gieryn 1995) er relevant ift. at forstå funktionen af disse kategoriseringer. 'Grænsearbejde' begrebsliggør det kontinuerlige arbejde med at skabe grænser mellem det strikt videnskabelige og alt, hvad der er ikke-videnskabeligt (Gieryn 1983, 781f). Det er en praksis, som foregår i mange sammenhænge: fx når biologilærere sætter Darwin på skemaet, men ikke skabelsesberetningen. Ifølge Gieryn sker grænsearbejdet altid med en form for strategisk mål for øje (Gieryn 1983, 783). Eksempelvis viser han, hvordan engelske fysikere skabte en grænse mellem teoretisk fysik som 'videnskabeligt' og ingeniørarbejde som 'bare teknik' i Viktoriatidens England for at sikre de universitetstilknyttede fysikere øget finansiering. Det betyder dog ikke, at grænsearbejde skal forstås som en bevidst, rationel praksis. Begrebet er rundet af en konstruktivistisk tankegang, hvor konteksten i høj grad former målsætningen (Gieryn 1983, 782). Når LU arbejdede med at konstruere KiDs kritik, udførte de ofte grænsearbejde: Komponenter klassificeret som 'videnskab' forsøgtes inkluderet i kritikken, mens komponenter klassificeret som 'ikke-videnskab' blev udgrænset. I det følgende vil vi vise, hvorledes dette skete på multiple måder, samt hvordan det tjente det formål at skabe en bestemt form for kritik.

\section{Kampen om sandhederne}

Politik vs. videnskab

En meget tydelig form for grænsearbejde var LU's bestræbelser på at skille politik, som de mente, var forklædt som videnskab, fra 'ægte' videnskab. Dette grænsearbejde beroede på LUs forestillinger om institutionerne 'politik', 'videnskab' og arbejdsdelingen imellem dem. LU's medlemmer refererede meget tydeligt til en opfattelse af naturvidenskaben som en ideelt direkte og ren repræsentation af naturen - eller som én udtrykte det: „Det bedste bud på sandheden derude“. Politik blev i modsætning hertil omtalt som rent subjektive interesser og ideologier. Et medlem af LU forklarede disse definitioner af politik og videnskab meget klart på følgende måde:
„Altså, det må jo være noget om rangforhol- det mellem sandhed og interessevaretagelse eller ideologi. I en eller anden forstand må videnskaben, spørgsmålet om sandheden i empirien, det den tilsiger dig, have en højere rang end dine politiske ambitioner eller interesser. Hvorimod i politik er det jo selvføl- gelig i en eller anden forstand din ideologi, dine vælgere, eller hvad du nu repræsenterer, der har forrang."

I LU's diskussioner blev der jævnligt refereret til netop denne skelnen mellem videnskab og politik som repræsentationer af hhv. 'sandhed' og 'interesser'. Og i konstruktionen af KiD's kritik blev det en væsentlig komponent at bidrage til opretholdelsen af dette skel i debatten om klimaforandringerne. Et medlem af LU kaldte det en 'filterfunktion': At hjæelpe borgere med at skelne mellem objektiv videnskab og subjektive holdninger. I forlængelse heraf betragtede LU det også som en væsentlig del af KiD's rolle at formidle til befolkningen, når politik er 
forklædt som videnskab - eller med andre ord: når interesser er klædt ud som sandhed.

Det blev bl.a. tydeligt i de mange diskussioner af Bjørn Lomborgs udsagn og rolle i klimadebatten, hvor han bl.a. blev benævnt „en videnskabelig luder", der "glemmer at tage videnskabs-hatten af, nair han udtaler sig om ting, han ikke har videnskabeligt belag for at udtale sig om“. Et medlem af LU fremførte, at han „blev sat ind af Fogh-regeringen på et tidspunkt, hvor de havde brug for en videnskabelig krykke til at retfardiggøre, at man ikke skulle gøre noget med klimaområdet". Bjørn Lomborg fik altså status som forsker, men med politiske motiver: Man havde brug for nogle bestemte videnskabelige resultater til at retfærdiggøre en bestemt politik. Dette er ifølge LU meget problematisk og påkræver, at aktører som fx KiD opdager og afslører denne sammenblanding af videnskab og politiske interesser for befolkningen.

Diskussionen om Lomborg illustrerer på fin vis en form for grænsearbejde mellem videnskab og ikke-videnskab, som blev praktiseret i LU's diskussioner: Videnskab er sandhed - politik er interesser og dermed ikke-videnskab. Og de, som med videnskabelige termer argumenterer imod klimaforandringernes realitet, kan med rette mistænkes for at være motiveret af politiske interesser i højere grad end forpligtelsen på sandhed. Det bliver så KiD's rolle at 'afsløre' disse politiske motiver. I forlængelse heraf var LU bekymrede over de mange videnskabelige usikkerheder i forbindelse med klimaforandringerne, idet disse åbner en flanke for politiserede videnskabelige udsigelser om klimaforandringerne. For når man ikke kan sige med sikkerhed, hvad der er sandt og falsk, bliver der ifølge LU større spillerum for usande, politiske udsagn forklædt som bud på sandheden. Tilsvarende kan oprigtige bud på sandheden om klimaforandringerne afvises som forklædte politiske interesser. Derfor skal KiD hjælpe med at afgrænse den rene videnskab fra den del af videnskaben, som er besmittet med politiske interesser.

\section{James Hansen eller FN's klimapanel?}

En anden form for grænsearbejde var udelukkelsen af videnskabelige repræsentationer af klimaforandringerne, som enten er for politisk radikale eller for reaktionære. Med 'videnskabelige repræsentationer' mener vi udsagn om klimaforandringernes omfang og karakter, fx i form af udtalelser fremsat af videnskabelige eksperter. Latour bruger repræsentationsbegrebet til at vise, hvordan fænomener som fx klimaforandringerne ikke er synlige i sig selv. Vi kan kun diffust opfatte eller mærke klimaforandringerne, og derfor er der brug for repræsentanter, der kan tale på vegne af fænomenerne, så de bliver synlige for andre (Latour 2006, 193-194; Fuglsang 2004, 417). Disse repræsentationer kan være (og er ofte) forskning - det kan eksempelvis være nye resultater fra iskerneboringer på indlandsisen eller fortolkninger af solpletters betydning for klimaet på jorden. Under LU's møder i 2009 blev det diskuteret, hvorvidt de skulle støtte sig til IPCCs klimarapport fra 2007 eller klimaforskeren James Hansens anbefaling af $350 \mathrm{ppm}$ som $\mathrm{CO}_{2}$ grænse. Fælles for disse udsagn er, at de hævdes på et videnskabeligt grundlag at repræsentere klimaforandringerne.

To væsentlige kriterier for valget af videnskabelige repræsentationer var, om de forventedes at have legitimitet blandt den brede befolkning og at mane til større agtpågivenhed over for klimaforandringerne. LU var bekymret for at referere til videnskabelige repræsentationer, som ikke havde bred legitimitet. Det kom bl.a. til udtryk i diskussionerne om, hvorvidt de skulle referere til klimaforskeren James Hansens scenarier for klodens fremtid. En diskussion herom endte i en længere disput om, hvorvidt $\mathrm{KiD}$ skulle referere til hans forskning endte i en længere disput, om, hvorvidt KiD dermed ville komme til at virke "for hippie-agtige“. Det blev ivrigt diskuteret, om James Hansen er "for radikal“ og dermed ikke har legitimitet hos den brede befolkning. I disse diskussioner var vurderingskriteriet ikke LU's mening om de videnskabelige udsagns sandhedsværdi, men deres forestilling om den brede befolknings mening om denne sandhedsværdi. For som et landsudvalgsmedlem sagde:

\section{„Vi er nødt til at tage folks holdninger lidt i betragtning og så kan vi rykke lidt videre end det i stedet for at indtage en fuldstændig dommedagstilgang. For så er der ikke nogen, der gider høre på én."}

Hun mente altså, at det ikke nytter at referere til videnskabelige repræsentationer, som af befolkningen betragtes som pessimististiske - for så ender det bare med, at man ikke bliver hørt.

Men omvendt var det også LU magtpåliggende, at KiD's videnskabelige referencer ikke var for reaktionære. IPCC's rapport fra 2007 blev i sin tid vedtaget som bevægelsens videnskabelige grundlag, bl.a. fordi den på daværende tidspunkt ifølge LU havde stor legitimitet blandt befolkningen. Et af medlemmerne fortalte:

„IPCC's rapport kom jo som en befrielse, fordi en stor gruppe af forskere med FN's stempel på sagde, at nu er vi sgu ret sikre på, at ja, der er klimaforandringer og ja, de er menneskeskabte. Det var ligesom den reference, man kunne have." 
Således kunne IPCCs rapport dengang medvirke til at mobilisere borgere, idet der hermed ved hjælp af FN's signatur blev skabt legitimitet omkring nogle på daværende tidspunkt kontroversielle facts om klimaforandringerne. Men nu - i foråret 2009 - var situationen en anden: FN's klimarapport var ifølge LU blevet for „mainstream“ og ikke længere repræsentativ for den nyeste viden på området. Et medlem forklarede:

„Vi skal jo hele tiden være længere fremme end det, som er alment accepteret, for ellers så presser vi jo ikke nogen. Og hvis vi blev tilbage på IPCC - jamen det er jo det, de fleste er i dag. Så vi skal jo hele tiden være et skridt foran."

Således afgrænsede LU sig i konstruktionen af KiD's kritik både fra videnskabelige repræsentationer, som de forventede, at befolkningen opfatter som "for radikale", og repræsentationer, som er "for reaktionare" "Tilbage er så de videnskabelige repræsentationer, som har den rette balance. I foråret 2009 faldt valget efter lange diskussioner på James Hansens forskning, idet man mente, at han efterhånden var sluppet af med sit image som dommedagsprofet og havde opnået bred legitimitet.

I forlængelse af diskussionerne om James Hansens eventuelle image som dommedagsprofet blev det også ofte pointeret, at $\mathrm{KiD}$ ikke var en organisation med „et program for det gode samfund“, men - og dette blev fremstillet som en modsætning - „en strengt videnskabeligt baseret organisation “. De refererede ofte til en formulering fra bevægelsens grundlag om, at $\mathrm{KiD}$ er baseret på „den videnskabelige konsensus blandt klimaforskere" og tog aktivt afstand fra at blande „det rene klimaspørgsmål“ sammen med politiske spørgsmål om at forbedre samfundet. Fx i følgende citat:

„Du fremstiller det her lidt som om, det handler om at skabe en bedre verden. Det mener jeg jo altså ikke, at det gør. Det handler om at undgå en katastrofe, som vil ramme alt og alle, der har værdi her i verden. ... For mig er det her ikke et revolutionært projekt i den forstand - det handler ikke om at skabe en ny og bedre verden, hvor alle har det godt. Det handler om at undgå en katastrofe."

Denne skelnen mellem at „skabe en ny og bedre verden“" og at "undgå en katastrofe“ er et eksempel på de omfattende bestræbelser i LU på at definere KiD's tilgang til klimaproblemet som en rent videnskabeligt baseret vi- sion om at bremse klimaforandringerne i modsætning til ideologisk baserede løsningsforslag. Denne form for kritik blev stillet i modsætning til de politiske aktører, som ser klimaproblemet som en kamp om at skabe samfund med mindre ulighed og større omfordeling. I forbindelse med valget af videnskabelige repræsentationer foregik der således også et grænsearbejde med at adskille, hvad LU så som ikke-videnskabelige, ideologiske idéer om det gode samfund og det 'rent videnskabeligt' baserede ønske om at forhindre klimakatastrofen.

\section{Gronsearbejdets formål}

LU drog således grænser på multiple måder for at etablere $\mathrm{KiD}$ som en kritisk aktør på den klimapolitiske scene: Det er KiD's ansvar at råbe borgerne op, hvis politiske statements om klimaet 'forklædes' som videnskabelige facts. Desuden er det KiD's rolle at vise muligheden for en kritisk holdning til klimapolitikken, som er afgrænset fra en række relaterede politiske spørgsmål. Dermed åbnes muligheden for at kæmpe imod en klimakatastrofe uden at skulle forholde sig til fordelingspolitiske spørgsmål, som mange andre kritiske aktører - fx NOAH og Greenpeace - ifølge LU uhensigtsmæssigt bringer ind i debatten. Slutteligt er det vigtigt, at KiD refererer til videnskabelige repræsentationer af klimaforandringerne, som på én gang har bred legitimitet og mobiliserer til større ansvarstagen for klimaforandringerne.

Det, der lades tilbage efter disse forskellige former for grænsearbejde, er argumentet om, at KiD's rolle er baseret på videnskab, som tilstræber 'værdifrit' at afdække sandheden om klimaforandringerne. Men hvorfor? Hvad muliggør dette grænsearbejde? Ligesom Gieryn (1983) argumenterer for, at fysikernes grænsearbejde i Viktoriatidens England skete med et bestemt formål, vil vi også argumentere for, at LUs grænsearbejde tjener bestemte formål. Det danner nemlig på to måder grundlag for den kritik, som ifølge LU bør udøves: For det første mente LU's medlemmer, at referencen til den rene, værdifrie videnskab muliggør, at KiD kan appellere til den 'brede befolkning'. Som et medlem udtrykte det, burde klimasagen optage alle, „uanset om du er godsejer eller arbejdslos“. Og derfor skal KiD netop være en bred folkebevægelse. Men LU frygtede kontinuerligt, at $\mathrm{KiD}$ ville blive forbundet med venstrefløjen og dermed kun appellere til en smallere del af befolkningen. Som et medlem af LU sagde:

„Jeg er i hvert fald lidt forbeholden over for at gøre klimaspørgsmålet til en del af en større kamp for social lighed - altså for at gøre det til en venstrefløjssag. Fordi så tror jeg ikke, det kommer til at lykkes". 
Her bliver grænsearbejde væsentligt. For ved hjælp af værdifrie videnskabelige referencer søgtes politiske konflikter og interesseforskelle elimineret, hvorved LU håbede at mobilisere et bredt udsnit af borgere med forskellige politiske overbevisninger. I LU herskede der således en forestilling om, at konflikter og interesseforskelle vil blive elimineret, hvis blot der ved hjælp af videnskabelig oplysning skabes bevidsthed om klimaforandringerne. Denne idé kommer fx tydeligt til udtryk i følgende udtalelse fra et medlem af LU:

„Vi har den uudtalte opfattelse, at hvis folk bare vidste, hvordan det stod til, så ville de også tænke og handle anderledes."

Referencer til videnskabelige repræsentationer, som har bred legitimitet, giver således mulighed for at skabe konsensus, hvorved KiD kan appellere bredt. Videnskabelige udsagn skal således bruges til at skabe et fællesskab baseret på enighed på tværs af traditionelle politiske skel.

For det andet mente LU's medlemmer, at referencerne til den rene, værdifrie videnskab styrker argumentet om, at det er nødvendigt at forsøge at bremse klimaforandringerne. Blandt masserne er der ganske vist store konflikter om, hvad vi skal stille op i forhold til klimaforandringerne. Men disse konflikter er i LU's optik snarere en konflikt mellem de oplyste og de uoplyste end en modsætning mellem dem, der er for og dem, der er imod en mere ambitiøs klimapolitik. Konflikterne ville i LU's optik blive opløst, hvis blot der var tilstrækkelig formidling af de sande videnskabelige udsigelser om klimaforandringerne. Som et medlem af LU siger:

„... det burde være indlysende for enhver, hvis man sætter sig ind i, hvor alvorlige konsekvenser vi står over for, at der skal ske noget. Der skal ske noget alvorligt.“

Der er altså en tankegang om, at man på grundlag af den rette viden direkte kan udlede, hvad der politisk skal gøres. Det er ikke et spørgsmål om, hvad man politisk står for, men om man ved nok om klimaforandringerne. Og det er netop derfor, at grænsearbejde bliver så vigtigt: Det er KiD's opgave at oplyse om sandheden om, hvordan klimaforandringerne vil udvikle sig. Inkluderet i denne opgave er også, at $\mathrm{KiD}$ skal sortere de politiske, de reaktionære og de uddaterede videnskabelige udsigelser om klimaforandringerne fra, således at befolkningen holdes opdateret med, at det efterhånden ser mere og mere grelt ud. Et medlem af LU formulerer KiD's rolle meget præcist:

\begin{abstract}
„Nogle gange ser jeg også vores funktion som "bare" oplysende. At promovere videnskaben kan jo godt være politik i sig selv, fordi der er en kløft mellem videnskaben og det, befolkningen tror, er videnskab.“
\end{abstract}

Arbejdet med at drage grænser har altså bl.a. det formål at styrke argumentet om, at der skal 'ske noget alvorligt' ved at oplyse om, hvad den rigtige videnskab siger om klimaforandringerne.

\section{Alle er lige for Sandheden}

For at mobilisere en bred, folkelig bevægelse mod klimaforandringerne mener $\mathrm{LU}$, at $\mathrm{KiD}$ så at sige skal udøve kritik med begrundelse i 'videnskabelige fakta' for dermed at undgå prædikatet 'politiske' i forstanden 'partiske'. Dette skal skabe fælles forståelse frem for politisk konflikt og dermed grundlag for at tale med én stemme til politikerne. I det følgende vil vi se nærmere på, hvad det er for en form for kritik, vi hermed ser forsøgt konstrueret. Først vil vi kontekstualisere de tankegange, som er på spil i kritiklaboratoriet i forhold til dansk politisk kultur. Hermed tydeliggøres det, hvorledes diskussionerne i LU op til COP15 er en paradigmatisk case, der viser udfoldelsen af tankegange og traditioner, som er udbredt i tid og rum i en dansk kontekst. Hernæst udvikler vi begrebet 'falsk konfliktualitet' som betegnelse for den grundidé om kritik, som konstrueres i denne kontekst. Slutteligt vil vi diskutere implikationer og perspektiver ved denne idé om kritik. Formålet hermed er ikke at vurdere kritikken eller forudsige dens effekt, men at pege på aktualiteten af yderligere undersøgelser og diskussioner af brugen af videnskabelig viden i forbindelse med politisk kritik og folkelig mobilisering.

LU's konstruktion af kritik deler træk med den folkelige konsensustradition, som ifølge Horst \& Irwin er gennemsyrende for den danske demokratiske kultur (Horst \& Irwin 2010: 106). Idealet har rødder tilbage til Grundtvig og Højskolebevægelsen i midten af det nittende århundrede. Her blev der gjort op med den økonomiske og intellektuelle elites privilegerede adgang til viden og ideen om, at denne skulle være 'bedre vidende'. I stedet fremmede man almuens uddannelse, den almene dannelse og personligt engagement i samfundet som den gode form for viden. Håndens og åndens arbejde kunne ikke adskilles (Horst 2012). Desuden pointeredes dialog og samtale som den rette vej til et godt samfund. Ifølge denne tankegang vil dialog nødvendigvis mindske sociale og politiske konflikter, idet parterne gennem dialogen efterhånden vil nå til en fælles forståelse (Horst \& Irwin 2010: 111). Idealet har således ligheder med grundpræmissen i Jürgen Habermas' idé om deliberation gennem 
'det bedre arguments tvangsfrie tvang' (Habermas 1984). Traditionen slår igennem i danske parlamentariske normer om, at 'brede forlig over midten' er at efterstræbe og var grundstenen i Teknologirådets konsensuskonferencer om nye teknologier. Tilsvarende forventer LU, at dialog mellem de videnskabeligt uoplyste, hhv. oplyste vil føre til enighed og tilslutning til, at klimaforandringerne eksisterer og må bremses med de fornødne midler. Det er på grundlag af denne videnskabeligt baserede konsensus blandt befolkningen, at det folkelige krav om en mere ambitiøs klimapolitik skal rejses. Desuden ser de den folkelige konsensus som en betingelse for, at forandringer kan ske - en betingelse som ikke nødvendigvis ville ses $\mathrm{i}$ andre politiske kulturer. Således trækker LU's konstruktion af KiD’s kritik på tankegods om konsensus, som er en rodfæstet del af den danske politiske kultur, og søger så fundamentet for denne konsensus i nøje udvalgte videnskabelige fakta.

Som grundlag for deliberationen står 'videnskabelig sandhed' som ethvert arguments målestok. Den status, som videnskaben hermed tildeles ligner, hvad der inden for feltet 'Public Understanding of Science (PUS) kaldes 'the deficit model of science communication' (Horst 2003; Horst 2008a). Ifølge denne forestilling er det forskernes opgave at kommunikere et 'sandt' bud på, hvordan verden bør forstås og dermed det rette grundlag for at afgøre, hvordan samfundet skal agere. Man kan så at sige sætte en kausalpil mellem videnskab og politik i den forstand, at man kan udlede direkte af videnskabelig kommunikation, hvorledes man bør forholde sig til et givet fænomen. Herved elimineres politiske og ideologiske diskussioner til fordel for styring via en videnskabeligt baseret fornuft. Denne tankegang er at finde hos LU (selvom de ikke er forskere), når de ønsker at fjerne politik og ideologi fra debatten om klimaforandringerne for i stedet at bane vejen for videnskabeligt baserede adviseringer af de rette løsninger. LU's diskussioner er således præget af en idé om, at (klima)politik er problematisk, når den videnskabeligt baserede fornuft forplumres af politik og ideologi. 'The deficit model' forbindes ofte med intellektuel elitisme (Irwin \& Wynne 1996; Horst 2003). Men LU kombinerer den med idealerne om folkelig konsensus og ønsker egentlig ikke at være elitære. De prøver snarere at finde et uomtvisteligt samlingspunkt på tværs af forskellige politiske identiteter, for at kravet om en langt mere ambitiøs klimapolitik kan rejses.

LU's konstruktion af KiD's videnskabeligt baserede kritik kombinerer således et ideal om folkelig konsensus med en 'deficit model' forstålse af forholdet mellem videnskab og politik. Kritikken hviler hermed på en antagelse om, at befolkningens uenigheder om klimaforandringerne potentielt vil kunne opløses gennem en videnskabeligt baseret dialog, hvor en bred erkendelse af perspektiverne for klimaforandringerne fra et 'rent' videnskabeligt synspunkt uden ideologiske forstyrrelser fremmes. Herved vil der dannes konsensus om langt mere ambitiøse klimapolitikker. Konflikterne om klimaforandringerne er altså, i LU's optik 'falske konflikter', snarere end reel politisk uenighed. En tilstand af konflikt, som skyldes manglen på videnskabeligt baseret deliberation. Denne diagnose, som stilles af LU, og danner grundlag for konstruktionen af KiD's kritik, har vi valgt at benævne 'falsk konfliktualitet'. KiD's opgave er ifølge LU følgelig at opløse denne falske konfliktualitet ved at udbrede kendskabet til videnskab om klimaforandringerne, idet der hermed banes vej for en deliberation, som vil resultere i en fælles forståelse af klimaforandringerne og de nødvendige løsningsperspektiver.

Som antydet er begrebet 'falsk konfliktualitet' bl.a. inspireret af Marx og Engels. Både Marx og Engels bruger begrebet 'false consciousness' til at beskrive en tilstand, hvor arbejderne ikke forstår deres egne interesser, fordi de er underlagt borgerlig ideologi. Deres forståelse af nødvendigheden i deres situation, hvor de arbejder uden at have del i den rigdom, de producerer, er altså en tilstand af 'falsk bevidsthed' (Engels 1893/1975). Horst \& Irwin parafraserer dette begreb i deres artikel om teknologipolitik og den danske konsensustradition og taler om 'false consensusness' i dansk regulering af nye teknologier (Horst \& Irwin 2010). Dette begreb beskriver en (dansk) tilstand, hvor man pga. stærke normer om konsensus som den ideelle udgang af politiske diskussioner så at sige forcerer en lukning af konflikter for at skabe en i realiteten 'falsk konsensus'. Vi twister begrebet endnu engang for at kunne beskrive LU's forestilling om en helt tredje falsk tilstand, som nærmest er modsætningen til den 'falske konsensus'. 'Falsk konfliktualitet' beskriver en tilstand, hvor der forekommer at være politisk uenighed, men i realiteten ikke er det. Som i Marx' beskrivelse af arbejdernes falske bevidsthed skyldes falskheden en art ideologisk slør. I LU's diagnose er der tale om slør, som skaber ideer blandt befolkningen om, at der er stor uenighed om klimaforandringernes omfang og løsninger, men hvor der i realiteten er konsensus, hvis bare man eliminerede politiske interesser og ideologi.

\section{Konklusioner og perspektiver}

Begrebet om 'falsk konfliktualitet' beskriver en bestemt form for politisk kritik, som påberåber alene at være baseret på videnskab. Begrebet er konstrueret på baggrund af et casestudie af KiD’s LU i 2009, men peger på bredere implikationer - både for studier af sammenhænge mellem videnskab og sociale bevægelser og for studier af, hvordan særegne politiske kulturer performer i politikudvikling. I 
forhold til udbredelsen og agensen af 'the deficit model' viser analysen, at det ikke kun er indenfor forskningsprofessionen, at ideen om 'the deficit model' opretholdes. Den er snarere et tankesæt, som mange forskellige aktører abonnerer på og reproducerer i konkrete situationer. Det er en kollektiv forestilling om videnskabens rolle i samfundet, som også gør sig gældende i aktivistiske miljøer. Som tidligere beskrevet forstår Barry $(1999,2001)$ kritik som en praksis, der har til formål at etablere en ny sandhed. LU's projekt er også at etablere en sandhed: klimaforandringernes alvor og nødvendigheden af omfattende politisk regulering for at bremse dem. For at demonstrere denne sandhed trækker de på kendte, kulturelle måder at 'bevise' sandheden på. 'The deficit model' er en sådan kulturelt kendt måde. Og LU forventer derfor at kunne mobilisere bred opbakning til deres sag ved at henvise til det, som de finder, er et uomtvisteligt bevis for deres sandhed, nemlig videnskab om klimaforandringerne.

I forhold til forståelsen af betydningen af politiske kulturer for konstruktionen af kritik viser analysen, hvordan kombinationen af en tradition for konsensus og en 'deficit model' forståelse af videnskab influerer LU's konstruktion af kritik. Vi valgte netop KiD's LU som en paradigmatisk case, fordi det videnskabelige og folkelige er særligt udtalt i KiD i sammenligning med mange andre danske miljø- og klima-NGO'er. Af samme grund forventer vi ikke, at samme kritiske mission er at finde hos (alle) andre danske NGO'er. Men da idealet om konsensus og 'the deficit model' forståelse af videnskab netop er kulturelt udbredte forestillinger om politik og videnskab, forventes disse også at have betydning hos andre danske NGO'er og politiske aktører i det hele taget. Man kan være modstander af konsensuskulturen og mane til konflikt, men den er svær ikke at skulle forholde sig til.

Endvidere giver analysen anledning til refleksioner over brugen af videnskab i politisk kritik og - i et normativt perspektiv - mulighederne for en virksom klimakritik. Det kan problematiseres, hvorvidt det overhovedet er muligt at skabe et fællesskab alene baseret på 'værdifrie' og 'ikke-ideologiske' videnskabelige udsigelser (Waterton \& Wynne 1996; Latour 2007). I bogen „Why we disagree about climate change“ (Hulme 2009) argumenteres der for, at der i for høj grad fokuseres på klimaforandringerne som en videnskabeligt estimeret, fremtidig miljøtrussel og at dette skaber uløselige uenigheder, hvor forskellige parter slår hinanden i hovedet med diverse videnskabelige fakta. Snarere, argumenterer Hulme, skulle man se klimaforandringerne som en 'imaginær ressource'; et spejl, hvori man kan se vores individuelle og samfundsmæssige opførsel gengivet og forvrænget - og hvor samfundet kan sætte spørgsmålstegn ved, hvorvidt man vil blive ved med at forfølge samme materielle, kulturelle og spirituelle stier som hidtil (Hulme 2009: 357f). Her argumenteres der således for, at et fællesskab i højere grad kan opstå, hvis 'klimaforandringer' netop forstås som et narrativt og kulturelt fænomen, snarere end et udelukkende videnskabeligt. Samme pointe kan fremføres her: Det er vanskeligt at forestille sig, at det skulle være muligt at skabe bred tilslutning til en politisk mission, som ikke formulerer et bud på 'det gode samfund'. Et aktuelt eksempel på en sådan kritik i en dansk kontekst er Jørgen Steen Nielsens bog „Den store omstilling“ (Nielsen 2012), som bl.a. leverer en analyse af forbindelserne mellem den finansielle krise, råstofkrisen, fødevarekrisen og klimakrisen. Overfor en sådan kritik fremstår KiD’s kritik noget reduceret. Uanset om det lykkes at bekæmpe 'falsk konfliktualitet' lader LU det stå hen i det uvisse, hvilke strukturer, der forårsager klimakrisen, og dermed hvordan problemet konkret skal løses.

I tiden efter COP15 har KiD og LU sandsynligvis ændret sig. KiD’s hjemmeside viser, at man nu i højere grad engagerer sig i værdimæssige diskussioner om, hvordan klimaforandringere påvirker (og påvirkes af) sociale og økonomiske forhold. Desuden lader det til, at KiD nu i højere grad end tidligere har fokus på større bæredygtighed i almindelige borgeres hverdagsliv og ideer om selvorganiserende bæredygtige 'minisamfund' (Klimabevægelsen 2014). Fokusforskydningen kan have mange årsager. Vi vil gerne pege på en udbredt tendens til større fokus på lokale initiativer og 'bottom up' løsninger efter COP15, som i manges øjne beviste de nationale stater og det internationale samfunds vanskeligheder ift. at dæmme op for klimaforandringerne via politisk regulering (Wivel 2013; Skovgaard \& Blaxekjær 2013). På KiDs hjemmeside er der en database med mange forskellige kilder til viden om klimaforandringerne (Klimabevægelsen 2014). Billedet her er langt mere heterogent end $i$ 2009 og de forholder sig både til permakultur, solceller, vindmøller og oilsand. Hvis ambitionen ikke længere i samme grad er at bekæmpe 'falsk konfliktualitet', bliver funktionen af de videnskabelige repræsentationer måske snarere at inspirere til lokal 'grøn omstilling'. Det betyder dog ikke, at det Grundtvigianske islæt er forsvundet fra anvendelsen af videnskab, men at det er andre aspekter af denne kultur, som kommer i fokus: Forestillingerne om, at lægmænd gennem stort engagement og personlig stillingtagen kan - om end måske ikke „stoppe den globale opvarmning“ - skabe demokrati, meningsfyldte liv og bæredygtighed på længere sigt ved gode eksempler på praksis. I den forbindelse kan forskellige fortolkninger af klimaforandringerne og løsningsforslag bruges inspirerende uden at de på samme måde kommer i karambolage, fordi det snarere handler om 'det gode liv' end fakta om naturens tilstand. 
Stor tak til KiD's landsudvalg, som venligt og tålmodigt inddrog os i deres arbejde. Tak til Signe Blaabjerg Christoffersen, Trine Berling Villumsen og en anonym reviewer for gode og konstruktive kommentarer under arbejdet med artiklen.

\section{Litteratur}

Barnes, B. \& Bloor, D. 1982, 'Relativism. Rationalism and the Sociology of Knowledge', M. Hollis \& S. Lukes (red.), Rationality and Relativism, Basil Blackwell, Oxford pp. 21-47.

Barry, A 1999, 'Demonstrations: Sites and Sights of Direct Action', Economy \& Society, no. 1, 1999 pp. 75-94.

Barry, A 2001, Political Machines. Governing a Technological Society, The Athlone Press, London \& NY.

Butler, J. 1997, Excitable Speech: A Politics of the Performative, Routledge, New York.

Buys, L., R. Aird, K. Van Megen, E. Miller, J. Sommerfield 2014, 'Perceptions of climate change and trust in information providers in rural Australia' Public Understanding of Science 23 (2): 170-188.

Engels, F. 1893/1975 'Letter to Mehring', K. Marx and F. Engels, Selected Correspondances, Moskva, Progress Publishers.

Epstein, S. 1995, 'The construction of Lay-Expertise: AIDS and the Forging of Credibility', Science, Technology and Human Values, 1995: pp. 408-31.

Flyvbjerg, B. 1991, Rationalitet og magt. Det konkretes videnskab, København Akademisk Forlag.

Fuglsang, L. 2004, 'Aktør-netværksteori eller tingenes sociologi' i Videnskabsteori i samfundsvidenskaberne, J. Fuglsang \& P.B. Olsen (red.), Roskilde Universitetsforlag Frederiksberg.

Gibbons, M., Limoges, C. Nowotny, H. Schwartzman, S. Scott, \& M. Trow 1994, The new production of knowledge. The dynamics of science and research in contemporary societies, Sage, London.

Gieryn, T. 1983, 'Boundary-Work and the Demarcation of Science from Non-Science: Strains and Interests in Professional ideologies of Scientist', American Sociological Review, 1983: pp. 781-95.

Gieryn, T. 1995, 'Boundaries of Science' S. Jasanoff (red.), Handbook of Science and Technology Studies, London, SAGE Publications.

Habermas, J. 1984, The Theory of the Communicative Action, Beacon Press, Boston MA.

Hess, D. 2007, Alternative Pathways in Science and Industry. Activism, Innovation and the Environment in an Era of Globalization, MIT Press, Cambridge,.

Horst, M. 2003, Controversy and Collectivity - articulations of social and natural order in mass mediated representations of biotechnology, Samfundslitteratur, København.

Horst, M. 2008a, 'Cloning sensations: mass mediated articulations of responses to controversial biotechnology', Public Understanding of Science, (14) 2: 185-200.

Horst, M 2008b, 'The Laboratory of Public Debate: Understanding the Acceptability of Stem Cell Research', Science and Public Policy, nr. 3, 2008 pp. 197-205.

Horst, M. 2012, 'Deliberation, Dialogue or Dissemination: Changing the Objectives of Science Communication in Denmark', B. Schiele, M. Classens \& S. Shi (red.) Science Communication in the World Practises, theories, trends, Netherlands, Springer Publishers.

Horst, M. \& A. Irwin 2010, 'Nations at ease with Radical Knowledge. On Consensus, Consensusing and False Consensusness', Social Studies of Science, nr. 1, 2010 pp 105-26.

Hulme, M. 2009, Why we disagree about climate change. Understanding Controversy, Inaction and opportunity, New York, Cambridge.

Irwin, A. 1995, Citizen Science: A study of People, Expertise and Sustainable Development, London, Routledge.
Irwin, A., B. Wynne (red.) 1996, Misunderstanding Science. The Public Reconstruction of Science and Technology, Cambridge, Cambridge University Press.

Jamison, A. 2001, The Making of Green Knowledge. Environmental Politics and Cultural Transformation, Cambridge University Press, Cambridge.

Jasanoff, S. S.H. Kim 2009, 'Containing the Atom: Sociotechnical Imaginaries in the United States and South Korea', Minerva 47 (2): 119-146.

Jasanoff, S. 2011, 'Constitutional Moments in Governing Science and Technology', Science and Engineering Ethics 17(4): 621-638.

Klimabevægelsen 2009, Klimabevagelsens grundlag. 07.03.2009, webside: www.klimanetvaerk.dk/grundlag.

Klimabevægelsen 2014, 07.02.2014, webside: www.klimabevaegelsen. $\mathrm{dk}$.

Knorr-Cetina, K. 1999, Epistemological Cultures. How the Sviences make Knowledge, Cambridge, Harvard University Press.

Latour, B., Woolgar, S. 1979, Laboraory Life. The Social Construction of Scientific Facts, Princeton University Press, West Sussex.

Latour, B. 1983, 'Give Me a Laboratory and I Will Raise the World', KD Knorr-Cetina and. M Mulkay, Science Observed, Sage, London.

Latour, B. 1987, Science in Action, Harvard University Press, Cambridge.

Latour, B. 2004, Politics of Nature - how to bring the sciences into democracy, Harvard University Press, Harvard.

Latour, B. 2006, Vi har aldrig varet moderne, Hans Reitzels Forlag, København.

Latour, B. 2007, Ting. Hvorfor er dampen gået af kritikken? Fra kendsgerninger til anliggender, Kunstakademiets Arkitektskole, København.

Leander, A. 2014, 'Essential and Embattled Expertise: The KnowledgeExpert-Policy Nexus around the Saring Gas attack in Syria', Tidsskriftet Politik 17(2).

Macnaghten, P., Kearnes, M.B. \& Wynne, B. 2005, 'Nanotechnology, Governance, and Public Deliberation: What Role for the Social Sciences?', Science Communication 27(2): 268-291.

Marres, N. \& R. Rogers 2005, 'Recipe for tracing the Fate of Issues and their Publics on the Web', B. Latour \& P. Weibel (red.) Making Things Public - Atmospheres of Democracy, ZKM/Center for Art and Media, Karlsruhe.

Miller, S. 2001, 'Public Undestanding of Science in the Cross-roads', Public Understanding of Science 10 (1): 115-120.

Nielsen, J. S. 2012, Den store omstilling. Fra systemkrise til gron økonomi, Informations Forlag, København.

Nowotny, H. 2001, Rethinking Science. Knowledge and the Public in an Age of Uncertainty, Polity Press, Cambridge.

Sevelsted, A.L., Henriksen, L.F. 2008, Mikrofinansens udviklingsokonomiske infrastruktur - okonomer som protesedesignere og markedsarkitekter, Master thesis, Sociologisk Institut, Københavns Universitet, København.

Skovgaard, J. \& Blaxekjær, L. 2013, 'Global Klimapolitik: Fra Bali til Paris', Tidsskriftet Politik 2013 (3): 7-16.

Traweek, S. 1988, Beamtimes and Lifetimes. The world of high-energy Phycisists, Cambridge, Harvard University Press.

Wivel, A. 2013, 'Klimaaktivisme som udenrigspolitik: Helt central, men hvorfor egentlig?' Tidsskriftet Politik 2013 (3): 31-39.

Waterton, C., Wynne, B. 1996, 'Building the European Union: Science and the cultural dimensions of environmental policy', Journal of European Public Policy, (3):3, pp 421-40.

Wynne, B. 1996, 'May the sheep safely graze?' in S. Lash, B. Szerszynky \& B. Wynne (red.) Risk, Environment and Modernity - Towards a new Ecology, London, SAGE. 